\title{
INH ALT
}

H. Benkenstein, A. MïgGe

Zum Einfluß des pH-Wertes leichter Böden auf den Ertrag von Tulpen .

W. Blasse, I, Gritriner

Grundlagen der Mineraldüngerverreg nung - Ermittlung von Anwendungskonzentrationen für Steinobst . .

\section{P. Plietzsch, S. Richter}

Untersuchungen zur Ermittlung der Arbeitskräftestruktur in industriemäßig produzierenden Gewächshausanlagen

H. Вётt'her, H. FröhLICH, ('H. Hё'BNeR Ergebnisse zum komplexen Einfluß von Beregnung, Pflanzenbestand und Düngung auf den Ertrag, die Qualität und Lagerfähigkeit von Speisezwiebeln (Allium cepa L.) . . . . . . .

G. SANDKE

Abscisinsäuregehalt in Apfelblättern im Verlauf der Vegetationsperiode.

\section{СОДЕРЖАНИЕ}

Х. БенНенutтaйn, А. Мюrte:

O влиянии показателя $\mathrm{pH}$ пёгких почв на урожай тюльпанов

В. БЛАССЕ, И. ГРИТТНЕР

Основы внесения минератьных удобрений при дождевании - определение концентраций, необходимых для косточковых пород . . .

\section{П. Плитч, С. РихтеР}

Выявление структуры рабочей силы в тепличных хозяйствах, основанных на промышленных методах производства . . . . . . . . . 273
Х. БЁТХЕР, Х. ФРЁлИХ, К. ХювНЕР

Результаты комплексного воздействия дождевания, густоты посева и удобрения на урожай, качество и лежкость репчатого лука (Allium cepa L.). . . . . . . . . . . . .

\section{Г. ЗАНДКЕ}

Содержание абсцизпновой киялоты в листьях яблони в течение вегетационного периода . . . . . .

\section{CONTENTS}

H. Benkensteit, A. MÜGge

The influence of the $\mathrm{pH}$-value of light soils on the yield of tulips

W. Blasse, 1. Grittiner

Fundamentals of mineral fertilizer application by sprinkling - Determination of application rates for stone fruit . . . . . . . . .

P. P.lietzaseh, S. Richtek

Studies regarding the determination of labour force structure in greenhouses producing along industriallines

H. Böttcher, H. Fröhlich, Ch. HÜbNeR Results regarding the complex influence of sprinkler irrigation, plant density and fertilization on yield, quality and storing quality of onions ( $A l$. lium cepa $\mathrm{L}$ ().

\section{G. SANDKE}

Abscisinnic acid content in apple leaves during the vegetation period 